NASA/TM-2000-209772
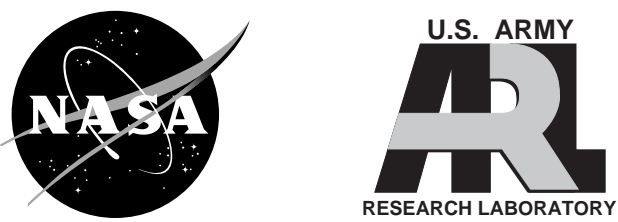

Experimental Heat Transfer and Bulk Air Temperature Measurements for a Multipass Internal Cooling Model With Ribs and Bleed

Douglas Thurman

U.S. Army Research Laboratory, Glenn Research Center, Cleveland, Ohio

Philip Poinsatte

Glenn Research Center, Cleveland, Ohio 
Since its founding, NASA has been dedicated to the advancement of aeronautics and space science. The NASA Scientific and Technical Information (STI) Program Office plays a key part in helping NASA maintain this important role.

The NASA STI Program Office is operated by Langley Research Center, the Lead Center for NASA's scientific and technical information. The NASA STI Program Office provides access to the NASA STI Database, the largest collection of aeronautical and space science STI in the world. The Program Office is also NASA's institutional mechanism for disseminating the results of its research and development activities. These results are published by NASA in the NASA STI Report Series, which includes the following report types:

- $\quad$ TECHNICAL PUBLICATION. Reports of completed research or a major significant phase of research that present the results of NASA programs and include extensive data or theoretical analysis. Includes compilations of significant scientific and technical data and information deemed to be of continuing reference value. NASA's counterpart of peerreviewed formal professional papers but has less stringent limitations on manuscript length and extent of graphic presentations.

- $\quad$ TECHNICAL MEMORANDUM. Scientific and technical findings that are preliminary or of specialized interest, e.g., quick release reports, working papers, and bibliographies that contain minimal annotation. Does not contain extensive analysis.

- CONTRACTOR REPORT. Scientific and technical findings by NASA-sponsored contractors and grantees.
- CONFERENCE PUBLICATION. Collected papers from scientific and technical conferences, symposia, seminars, or other meetings sponsored or cosponsored by NASA.

- SPECIAL PUBLICATION. Scientific, technical, or historical information from NASA programs, projects, and missions, often concerned with subjects having substantial public interest.

- TECHNICAL TRANSLATION. Englishlanguage translations of foreign scientific and technical material pertinent to NASA's mission.

Specialized services that complement the STI Program Office's diverse offerings include creating custom thesauri, building customized data bases, organizing and publishing research results ... even providing videos.

For more information about the NASA STI Program Office, see the following:

- Access the NASA STI Program Home Page at http://www.sti.nasa.gov

- E-mail your question via the Internet to help@sti.nasa.gov

- Fax your question to the NASA Access Help Desk at (301) 621-0134

- Telephone the NASA Access Help Desk at (301) 621-0390

- Write to:

NASA Access Help Desk

NASA Center for AeroSpace Information 7121 Standard Drive

Hanover, MD 21076 
NASA/TM-2000-209772

ARL-MR-471
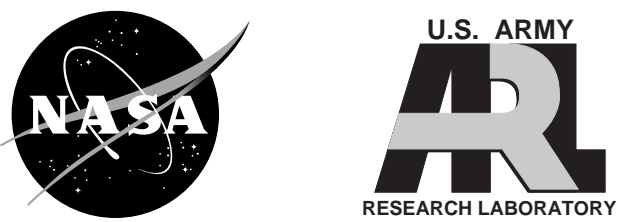

Experimental Heat Transfer and Bulk Air Temperature Measurements for a Multipass Internal Cooling Model With Ribs and Bleed

Douglas Thurman

U.S. Army Research Laboratory, Glenn Research Center, Cleveland, Ohio

Philip Poinsatte

Glenn Research Center, Cleveland, Ohio

Prepared for the

45th ASME International Gas Turbine Institute

sponsored by the American Society of Mechanical Engineers

Munich, Germany, May 8-11, 2000

National Aeronautics and

Space Administration

Glenn Research Center 
This report is a preprint of a paper intended for presentation at a conference. Because of changes that may be made before formal publication, this preprint is made available with the understanding that it will not be cited or reproduced without the permission of the author.

Available from

NASA Center for Aerospace Information 7121 Standard Drive

Hanover, MD 21076

Price Code: A03
National Technical Information Service 5285 Port Royal Road Springfield, VA 22100 Price Code: A03 


\title{
EXPERIMENTAL HEAT TRANSFER AND BULK AIR TEMPERATURE MEASUREMENTS FOR A MULTIPASS INTERNAL COOLING MODEL WITH RIBS AND BLEED
}

\author{
Douglas Thurman \\ U.S. Army Research Laboratory \\ Glenn Research Center \\ Cleveland, Ohio 44135 \\ Philip Poinsatte \\ National Aeronautics and Space Administration \\ Glenn Research Center \\ Cleveland, Ohio 44135
}

\begin{abstract}
An experimental study was made to obtain heat transfer and air temperature data for a simple 3-leg serpentine test section that simulates a turbine blade internal cooling passage with trip strips and bleed holes. The objectives were to investigate the interaction of ribs and various bleed conditions on internal cooling and to gain a better understanding of bulk air temperature in an internal passage. Steady state heat transfer measurements were obtained using a transient technique with thermochromic liquid crystals. Trip strips were attached to one wall of the test section and were located either between or near the bleed holes. The bleed holes, used for film cooling, were metered to simulate the effect of external pressure on the turbine blade. Heat transfer enhancement was found to be greater for ribs near bleed holes compared to ribs between holes, and both configurations were affected slightly by bleed rates upstream. Air temperature measurements were taken at discreet locations along one leg of the model. Average bulk air temperatures were found to remain fairly constant along one leg of the model.
\end{abstract}

\section{NOMENCLATURE}

$\beta \quad$ nondimensional time

c specific heat of test section material

$c_{p} \quad$ specific heat of air

D square channel height

$\mathrm{D}_{\mathrm{h}} \quad$ hydraulic diameter

e rib height

h heat transfer coefficient

$\mathrm{k}$ thermal conductivity

$\mathrm{m}_{\text {total }}$ total mass flow

$\mathrm{Nu} \quad$ local Nusselt number, $\mathrm{Nu}=\mathrm{hD} / \mathrm{k}$

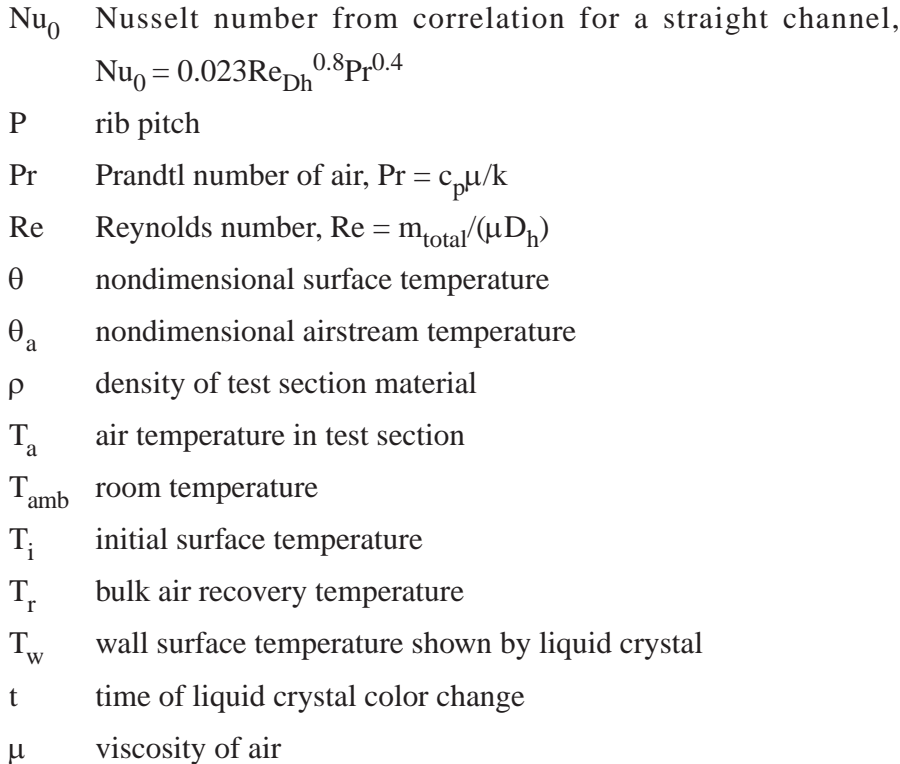

\section{INTRODUCTION}

With current and future jet engine designs requiring higher pressure ratios and operating temperatures, it is important for the engine materials to withstand these extreme conditions. One method of keeping turbine blade temperatures below the critical metal temperature level is to cool the blade by routing cooling air from the compressor through turbulated serpentine passages in the blades. Small amounts of this coolant can then be bled into the external boundary layer flow through discrete holes on the surface of the blade, forming an insulating layer of cool air between the blade and the hot combustion gas. Predicting the metal temperatures correctly requires quality experimental data, 
especially to validate turbomachinery CFD codes often used in the design of engine components.

Many experimental studies have considered the effects of Reynolds number and different rib geometries on the heat transfer of internal cooling channels, such as Lau, et al. (1991), Han (1988), Chyu (1991), Zhang, et al. (1994), Wang (1996), and Taslim, et al. (1994). Recently there have been experimental studies on the combination of internal cooling with ribs and bleed. Taslim, et al. (1995) studied the effects of bleed holes on heat transfer on a trapezoidal internal cooling channel. Shen, et al. (1996) reported on heat transfer enhancement in a converging straight internal cooling channel with ribs and staggered bleed holes. Ekkad, et al. (1996) studied heat transfer in a turbulated two-pass channel with ribs between bleed holes. Rigby, et al. (1997), Stephens, et al. (1995), Bonhoff, et al. (1996), and McDonough, et al. (1999) have used these experimental studies to validate numerical predictions for complicated internal cooling geometries. However in a typical turbine blade passage, bleed holes may not be spaced equidistant between ribs. Also the varying pressure gradient on the external surface of a blade may affect the flow bled from the internal cooling channel, resulting in nonuniform bleed flow rates. The present study focuses on varying bleed rates and rib placement relative to hole locations.

This report provides experimental heat transfer data for the first leg of a serpentine internal cooling channel with trip strips and bleed holes. A transient liquid crystal technique, as described by Hippensteele (1993), was used to determine the surface heat transfer coefficients. Ribs were placed at two locations relative to the bleed holes. One case had ribs spaced equidistant between the holes; the other case had ribs just upstream of the holes. Different bleed conditions (uniform bleed flow rate, increasing bleed flow rate per hole, decreasing bleed flow rate per hole, no bleed) were run to examine the effects of variable bleed on internal cooling. Experimental data were also obtained on bulk air temperatures in the channel.

\section{APPARATUS}

The overall test facility is shown in Fig. 1. Room temperature air was drawn into the tunnel by a vacuum exhaust system. An elliptical 1-D aluminum bellmouth was attached to the clear acrylic plastic test section. An orifice at the exit of the test section measured the mass flow rate. Eight adjustable flow meters were attached to the bleed holes of the test section. The bleed air was collected into a manifold and flows through an orifice to determine the overall bleed mass flow rate. Tunnel flow started when a ball valve was opened downstream of the orifices. The model was enclosed in an oven covered with an automatic temperaturecontrolled heater blanket. Two "cool" HSI lamps and a color digital CCD camera were used to view the model. Video images were stored in computer memory at 1 frame/sec using a commercial video frame grabber and were backed up on S-VHS videotape at 30 frames/sec. A time-date generator was also used to record the time with the video data.

The test section, made of $1.91 \mathrm{~cm}$ (0.75 in.) thick acrylic walls, had two partitions to create a serpentine channel, as shown in Fig. 2 . The first and second legs of the model were $6.67 \times 6.67 \mathrm{~cm}(2.625 \times 2.625 \mathrm{in}$. $)$ crosssection; the third leg was $6.67 \times 3.3 \mathrm{~cm}(2.625 \times 1.3$ in. $)$. Rounded trip strips, also made of acrylic, were attached to the lower surface of the model on all 3 legs, spaced $5.08 \mathrm{~cm}$ ( 2 in.) apart and oriented $90^{\circ}$ to the airflow. The rib height-to-channel height ratio (e/D) was 0.076; the rib pitch-toheight ratio (P/e) was 10 . Eight $0.38 \mathrm{~cm}(0.15$ in.) diameter bleed holes, spaced $5.08 \mathrm{~cm}$ (2 in.) apart, were drilled normal into the lower surface of the first leg only.

Liquid crystals, by virtue of their ability to change color with temperature, were used to determine surface temperature measurements. The lower surface of the model was sprayed with flat black lacquer, then with narrow-band microencapsulated chiral nematic liquid crystal paint for measuring the surface temperature to determine heat transfer. The video camera was perpendicular to the lower surface of the test section. Static pressures were measured on the lower surface of the model at the locations shown in Fig. 3(a). Open-ball thermocouple probes were placed in the airstream through the sidewall of the first leg and through the upper surface at the turns and ends of the channels, as shown in Figs. 3(b) and (c). Thin-foil surface thermocouples were attached to the lower surface for calibrating the liquid crystals. Temperature and pressure data were recorded by a PC-based data acquisition system.

\section{PROCEDURE}

Once the mainstream and bleed flow regulators were set, the test model was heated in the oven to a uniform temperature, typically between 54.4 and $65.6{ }^{\circ} \mathrm{C}\left(130\right.$ to $\left.150{ }^{\circ} \mathrm{F}\right)$. After the model reached the desired temperature, the cameras were turned on, and the data acquisition system and VCR were started. Then the oven was opened up and the flow valve opened, initiating airflow which suddenly cooled the model with room temperature air. The resulting liquid crystal color patterns, showing continuous surface temperature, were recorded. In the present study, only data from the first leg of the test section were examined. The yellow color band of the liquid crystal was used for calculating the heat transfer coefficients and was calibrated to be $37.8^{\circ} \mathrm{C}\left(100.1{ }^{\circ} \mathrm{F}\right)$. Video images were reduced using a video frame grabbing board, employing HSI color definition, and commercial software that extracts color and therefore surface temperature. The software also allowed manual digitization of the video images where high temperature gradient regions are difficult to resolve automatically.

Assuming that lateral conduction is negligible compared to heat flow normal to the surface, surface heat transfer coefficients can be calculated using the 1-D transient conduction equation:

$$
\theta=1-\exp \left(\beta^{2}\right)^{*} \operatorname{erfc}(\beta)
$$

where

$$
\theta=\left(\mathrm{T}_{\mathrm{i}}-\mathrm{T}_{\mathrm{w}}\right) /\left(\mathrm{T}_{\mathrm{i}}-\mathrm{T}_{\mathrm{r}}\right), \quad \beta=\mathrm{h} *(\mathrm{t} / \mathrm{\rho ck})^{0.5},
$$

$T_{i}$ is the initial surface temperature, $T_{w}$ is the wall surface temperature, $\mathrm{T}_{\mathrm{r}}$ is the bulk air recovery temperature, and $\mathrm{t}$ is the time from the start of the test. Note that this assumption is not actually valid near the bleed holes nor on the ribs. The local heat transfer coefficient, h, was calculated at the location of the calibrated liquid crystal color band. This isotherm also represents a uniform heat transfer coefficient when the bulk temperature is constant. Bulk temperature measurements in general showed little average increase along the passage, so the data were reduced using a single average temperature at the inlet.

Two test model configurations were employed, one with ribs equidistant between bleed holes, and one with ribs $0.51 \mathrm{~cm}(0.2 \mathrm{in}$.) upstream of bleed holes. Each configuration was run for three flow rates (nominal $\operatorname{Re}_{\mathrm{Dh}}=31,000 ; 61,000$; and 96,000) and four bleed cases (no bleed, uniform bleed, increasing bleed, and decreasing bleed). Reynolds numbers were based on channel hydraulic diameter, which is equal to the length 
of the side of the square channel. Using the present hardware, bleed flow rates of 5 to 10 percent of the main flow could be attained. Table 1 shows the nominal bleed flow rate per hole as percentages of total bleed flow. Air temperature measurements were taken in the first leg at several crosssectional stations as well as throughout the test section at discrete locations, as shown in Fig. 3.

An uncertainty analysis was performed following the method of Kline and McClintock (1953). Based on the following uncertainties: $\mathrm{T}_{\mathrm{i}}=$ $\pm 0.56{ }^{\circ} \mathrm{C}\left( \pm 1^{\circ} \mathrm{F}\right), \mathrm{T}_{\mathrm{w}}= \pm 0.28^{\circ} \mathrm{C}\left( \pm 0.5^{\circ} \mathrm{F}\right), \mathrm{T}_{\mathrm{r}}= \pm 0.83^{\circ} \mathrm{C}\left( \pm 1.5^{\circ} \mathrm{F}\right)$, and $\mathrm{t}= \pm 0.3 \mathrm{sec}$, the overall uncertainties in $\mathrm{h}$ for the multiple cases ranged from 8 to 13 percent.

\section{RESULTS AND DISCUSSION}

The flow rate conditions referred to in the discussion below as $\operatorname{Re} 1$, $\operatorname{Re} 2$, and $\operatorname{Re} 3$ were run at nominal Reynolds numbers of 31000, 61000, and 96000 respectively. When bleed was employed, the bleed flow rates were nominally 10,5 , and 5 percent of the inlet mass flow for $\operatorname{Re} 1, \operatorname{Re} 2$, and $\operatorname{Re} 3$, respectively. A typical inlet velocity profile (station 1 ) is presented in Fig. 4(a); inlet freestream turbulence intensity was nominally 2 percent.

\section{Bulk air temperatures and static surface pressures}

Airstream temperature measurements were taken for flow with uniform and no bleed at various cross-sections in the first passage, as shown in Fig. 3(b). Raw temperature versus time data from inlet temperature measurements are shown in Fig. 4(b) for Re3 and uniform bleed along with a running average of the four temperatures. The standard deviation of these inlet temperatures was $0.78^{\circ} \mathrm{C}\left(1.4^{\circ} \mathrm{F}\right)$; the fluctuations decrease moving down the channel. To examine temperature change through the duct, the fluctuations were eliminated by taking a $10 \mathrm{sec}$ average at $30 \mathrm{sec}$ after the start of the test. This is around the midpoint of typical liquid crystal data. Since room temperature and the initial heated airstream temperature could vary for each test case, a nondimensional temperature ratio was used to normalize the temperature measurements. The normalized air temperatures were calculated as

$$
\theta_{\mathrm{a}}=\left(\mathrm{T}_{\mathrm{a}}-\mathrm{T}_{\mathrm{amb}}\right) /\left(\mathrm{T}_{\mathrm{i}}-\mathrm{T}_{\mathrm{amb}}\right) .
$$

Normalized airstream temperatures at Re3 with uniform bleed are presented in Fig. 5 for four different heights from the floor of the model. Note that the data points at $x=58.4 \mathrm{~cm}$ (23 in.) are actually in the first turn region. As seen in the figures, the temperature variations in the spanwise direction are generally greater than the overall temperature increase or decrease in the streamwise direction. Similar effects were seen for $\operatorname{Re} 1$ and $\operatorname{Re} 2$, with generally more temperature variation spanwise than streamwise, and spanwise variations becoming slightly greater with increasing Reynolds number. The average cross-sectional temperatures for all of the cases remained fairly constant through the channel.

Spanwise air temperature averages throughout the test section (stations shown in Fig. 3(a)) at mid-channel height and at Re3 are shown in Fig. 6. The average temperature remains fairly constant from the inlet to station 3, the midpoint of the first turn. There is a noticeable increase between the turn and the inlet to the second leg. The average temperature stays constant from station 4 through the midpoint of the second turn, station 6 , then again increases.
Static pressure measurements, shown in Fig. 7, were taken on the lower surface at the stations shown in Fig. 3(a). Static pressure changes little through the first passage and the first turn. The pressure then begins to decrease halfway down the second passage and decreases further as the flow speeds up through the narrower third passage.

\section{Heat transfer}

Heat transfer is presented as the ratio of Nusselt number, $\mathrm{Nu}=$ $\mathrm{hD} / \mathrm{k}$, over the Nusselt number for fully developed pipe flow, $\mathrm{Nu}_{0}=$ $0.023\left(\operatorname{Re}_{\mathrm{Dh}}{ }^{0.8}\right)\left(\operatorname{Pr}^{0.4}\right)$. Data were not generally taken on the rib surfaces since the ribs were rounded and their small size violates the 1-D conduction assumption. Nusselt number ratio distributions discussed below are for $\mathrm{Re} 1$. The trends for $\mathrm{Re} 2$ and $\mathrm{Re} 3$ are similar.

Ribs between holes. Heat transfer distributions for ribs between bleed holes are shown in Fig. 8. With or without bleed, it can be seen that there is very low heat transfer just downstream of the ribs where separation and reattachment of the flow occur. Figure 8(a) shows the no bleed case, in which the total bleed flow was shut off, so no flow exited through the bleed holes. As seen in the figure, no effect from the holes is evident.

Having some type of bleed can greatly enhance surface heat transfer. The patterns produced by bleed with ribs between holes are backwardC-shaped compared to the oval shapes for the no bleed case. These patterns are also observed in Ekkad, et al. (1996) and Shen (1996). For the three cases with bleed, the effect of the bleed holes can readily be seen, with higher $\mathrm{h}$ immediately downstream of the hole. The boundary layer is essentially bled off, and heat transfer resistance is thereby reduced. For the uniform bleed case, there is much higher heat transfer near each hole as well as away from the hole near the ribs and walls, compared to the no bleed case. The heat transfer distributions appear to be periodic except in the region around hole 1 due to developing flow and around hole 8 due to the flow turning around the partition.

For the metered bleed flow cases, higher Nusselt ratios are seen near the holes with higher bleed flow rates. The ramped increasing bleed results are shown in Fig. 8(c). It can be seen that upstream, where the bleed flow rates are less than those for the uniform bleed case, heat transfer is similar to no bleed. Downstream, where bleed rates are higher than uniform bleed, heat transfer is similar to the uniform bleed case, but with slightly higher Nusselt ratios near and away from the hole. Near holes 4 and 5 where bleed rates are similar to the uniform bleed rates, heat transfer is slightly better than without bleed but not as good as with uniform bleed.

The ramped decreasing bleed results are shown in Fig. 8(d). Upstream, where bleed rates are higher than uniform bleed rates, heat transfer is higher near the hole and about the same as the uniform bleed case away from the hole. Heat transfer downstream is similar to the no bleed case. Heat transfer near holes 4 and 5 are slightly better than without bleed, but not as good as with uniform bleed.

It can be seen from these cases that higher bleed rates yield higher heat transfer values near and away from the hole. By comparing the distributions near holes 4 and 5, upstream bleed conditions seem to have a slight effect on heat transfer down the channel. Higher or lower bleed upstream reduces the heat transfer downstream away from the hole. Uniform bleed appears to give better heat transfer enhancement overall.

Ribs near holes. Heat transfer distributions for ribs near bleed holes are shown in Fig. 9. Figure 9(a) shows that the no bleed case is similar to Fig. 8(a). Figures 9(b) to (d) show that heat transfer is greatly enhanced near the downstream edge of the ribs due to the bleeding of the 
stagnant separated flow behind the rib. The patterns produced by bleed are C-shaped, opposite that produced by the ribs-between-holes configuration.

Other than the mirrored patterns, the heat transfer trends for each case are similar to those for ribs between holes. For uniform bleed, heat transfer distributions are periodic with higher Nusselt numbers near the bleed holes. Downstream of the hole, near the upstream edge of the rib, the effect of bleed is reduced.

Heat transfer upstream for the increasing bleed case is similar to the no bleed case; heat transfer downstream is similar to the uniform bleed case, only with slightly better enhancement away from the hole. Near holes 4 and 5 where bleed rates are about the same as those with uniform bleed, Nusselt values away from the hole are similar to those for uniform bleed and higher near the hole.

With decreasing bleed, heat transfer upstream is similar to the uniform bleed case, with higher Nusselt values near and away from the hole. Heat transfer downstream is better than without bleed but not as good as with uniform bleed. Near holes 4 and 5, heat transfer is similar to uniform bleed away from the hole, but is higher near the hole.

By comparing the distributions near holes 4 and 5, it appears that the decreasing bleed case gives better heat transfer enhancement. When comparing to the ribs-between-holes configuration, better heat transfer enhancement is seen near and away from the hole due to the bleeding of the separated flow behind the rib, which decreases the heat transfer resistance at the surface.

Reynolds number effect. Overall, heat transfer enhancement tends to decrease with increasing Reynolds number. As illustrated in Fig. 10 , increasing the Reynolds number for the uniform bleed case decreases the Nusselt number ratio only slightly. This is also true for all of the other cases not shown. For the cases with bleed, the heat transfer augmentation from increased mixing and boundary layer removal is less pronounced at higher Reynolds numbers. Generally for all cases with bleed, the patterns in the region around hole 1 appear to be squeezed toward the center of the channel as Reynolds number increases.

Centerline comparison. Centerline heat transfer coefficients for the region around hole 4, between the fourth and fifth ribs, are shown in Fig. 11 for both rib-between-hole and rib-near-hole cases. The highest heat transfer can be seen to occur on the top surface of the rib and downstream of the hole; it should be noted that the data at the peaks were taken within a few seconds of the startup and thus have uncertainties substantially higher than the nominal 10 percent uncertainty reported for the more conditioned data. The lowest heat transfer occurs downstream of the rib and then gradually increases approaching the hole. Reynolds number does not appear to affect the heat transfer in this region between the rib and hole.

\section{CONCLUSION}

Bulk air temperature measurements taken in the first passage showed that in general, temperature variations in the spanwise direction were greater than the overall variation in the streamwise direction. The average cross-sectional temperatures remained fairly constant along the channel. Large temperature jumps occurred between the half-point around the first turn and the inlet to the second passage.

Experimental heat transfer measurements showed that any amount of bleed would enhance surface heat transfer. Placement of ribs with respect to holes had a major effect on surface heat transfer distributions.
Placing ribs near bleed holes greatly enhances the heat transfer by cooling more surface area and removing the separated flow near the downstream edge of the rib. Different distribution patterns were also observed; the ribs-between-holes configuration produced backward-C-shaped patterns, while the ribs-near-holes configuration produced $\mathrm{C}$-shaped patterns. By comparing the heat transfer distributions near the center of the channel where the bleed rates were similar, heat transfer enhancement was found to be affected slightly by the bleed rates upstream. Higher or lower bleed flow upstream reduced the heat transfer downstream for the ribsbetween-holes configuration, while heat transfer enhancement for the ribs-near-holes configuration increases slightly with higher bleed rates upstream.

\section{REFERENCES}

Bonhoff, B., Tomm, U., Johnson, B.V., 1996, "Heat Transfer Predictions for U-shaped coolant channels with Skewed Ribs and with Smooth Walls," ASME Paper 96-TA-7.

Chyu, M.K., 1991, "Regional Heat Transfer in Two-Pass and ThreePass Passages with 180-deg Sharp Turns," ASME Journal of Heat Transfer, Vol. 113, pp. 63-70.

Ekkad, S.V., Huang, Y., and Han, J.C., 1996, "Detailed Heat Transfer Distributions in Two-Pass Smooth and Turbulated Square Channels with Bleed Holes," 1996 National Heat Transfer Conference, Houston, TX, Vol. 8, pp. 133-140.

Han, J.C., 1988, "Heat Transfer and Friction Characteristics in Rectangular Channels with Rib Turbulators," ASME Journal of Heat Transfer, Vol. 110, pp. 321-328.

Hippensteele, S.A. and Poinsatte, P.E., 1993, "Transient LiquidCrystal Technique Used to Produce High-Resolution Convective HeatTransfer-Coefficient Maps," NASA TM-106083.

Kline, S.J. and McClintock, F.A., 1953, "Describing Uncertainties in Single-Sample Experiments," Mechanical Engineering, Vol. 75, pp. 3-8.

Lau, S.C., McMillan, R.D., and Han, J.C., 1991, "Heat Transfer Characteristics of Turbulent Flow in a Square Channel with Angled Discrete Ribs," ASME Journal of Turbomachinery, Vol. 113, pp. 367-374.

McDonough, J.M., Garzon, V.E., and Schulte, D.E., 1999, "Effect of Film-Cooling Hole Location on Turbulator Heat Transfer Enhancement in Turbine Blade Internal Air-Cooling Circuits," ASME Paper 99-GT-141.

Rigby, D.L., Steinthorsson, E., and Ameri, A.A., 1997, "Numerical Prediction of Heat Transfer in a Channel With Ribs and Bleed," ASME Paper 97-GT-431.

Shen, J.R., Wang, Z., Ireland, P.T., Jones, T.V., and Byerley, A.R., 1996, "Heat Transfer Enhancement Within a Turbine Blade Cooling Passage Using Ribs and Combinations of Ribs With Film Cooling Holes," Transactions of the ASME Journal of Turbomachinery, Vol. 118, pp. 428-434.

Stephens, M.A., Shih, T.I-P., and Civinskas, K.C., 1995, "Computation of Flow and Heat Transfer in a Rectangular Channel with Ribs," AIAA Paper 95-0180.

Taslim, M.E., Li, T., and Spring, S.D., 1995, "Experimental Study of the Effects of Bleed Holes on Heat Transfer and Pressure Drop in Trapezoidal Passages With Tapered Turbulators," Transactions of the ASME Journal of Turbomachinery, Vol. 117, pp. 281-289. 
Taslim, M.E. and Spring, S.D., 1994, "Effects of Turbulators Profile and Spacing on Heat Transfer and Friction in a Channel," AIAA Journal of Thermophysics and Heat Transfer, Vol. 8, No. 3, pp. 555-562

Wang, Z., Ireland, P.T., Kohler, S.T., and Chew, J.W., 1996, "Heat Transfer Measurements to a Gas Turbine Cooling Passage with Inclined Ribs," ASME Paper 96-GT-542.
Zhang, Y.M., Gu, W.Z., and Han, J.C., 1994, "Heat Transfer and Friction in Rectangular Channels with Ribbed or Ribbed-Grooved Walls," ASME Journal of Heat Transfer, Vol. 116, pp. 58-65.

TABLE 1.-NOMINAL \% OF TOTAL BLEED FLOW IN EACH HOLE

\begin{tabular}{|l|c|c|c|c|}
\hline \multicolumn{1}{|c|}{ Hole \# } & $\begin{array}{c}\text { Uniform } \\
\text { bleed }\end{array}$ & $\begin{array}{c}\text { Increasing } \\
\text { bleed }\end{array}$ & $\begin{array}{c}\text { Decreasing } \\
\text { bleed }\end{array}$ & $\begin{array}{c}\text { No } \\
\text { bleed }\end{array}$ \\
\hline 1 Inlet & 12.5 & 0 & 24.4 & 0 \\
\hline 2 & 12.5 & 4.3 & 21.0 & 0 \\
\hline 3 & 12.5 & 7.6 & 17.6 & 0 \\
\hline 4 & 12.5 & 10.9 & 14.3 & 0 \\
\hline 5 & 12.5 & 14.3 & 10.9 & 0 \\
\hline 6 & 12.5 & 17.6 & 7.6 & 0 \\
\hline 7 & 12.5 & 21.0 & 4.3 & 0 \\
\hline 8 End of first passage & 12.5 & 24.4 & 0 & 0 \\
\hline
\end{tabular}

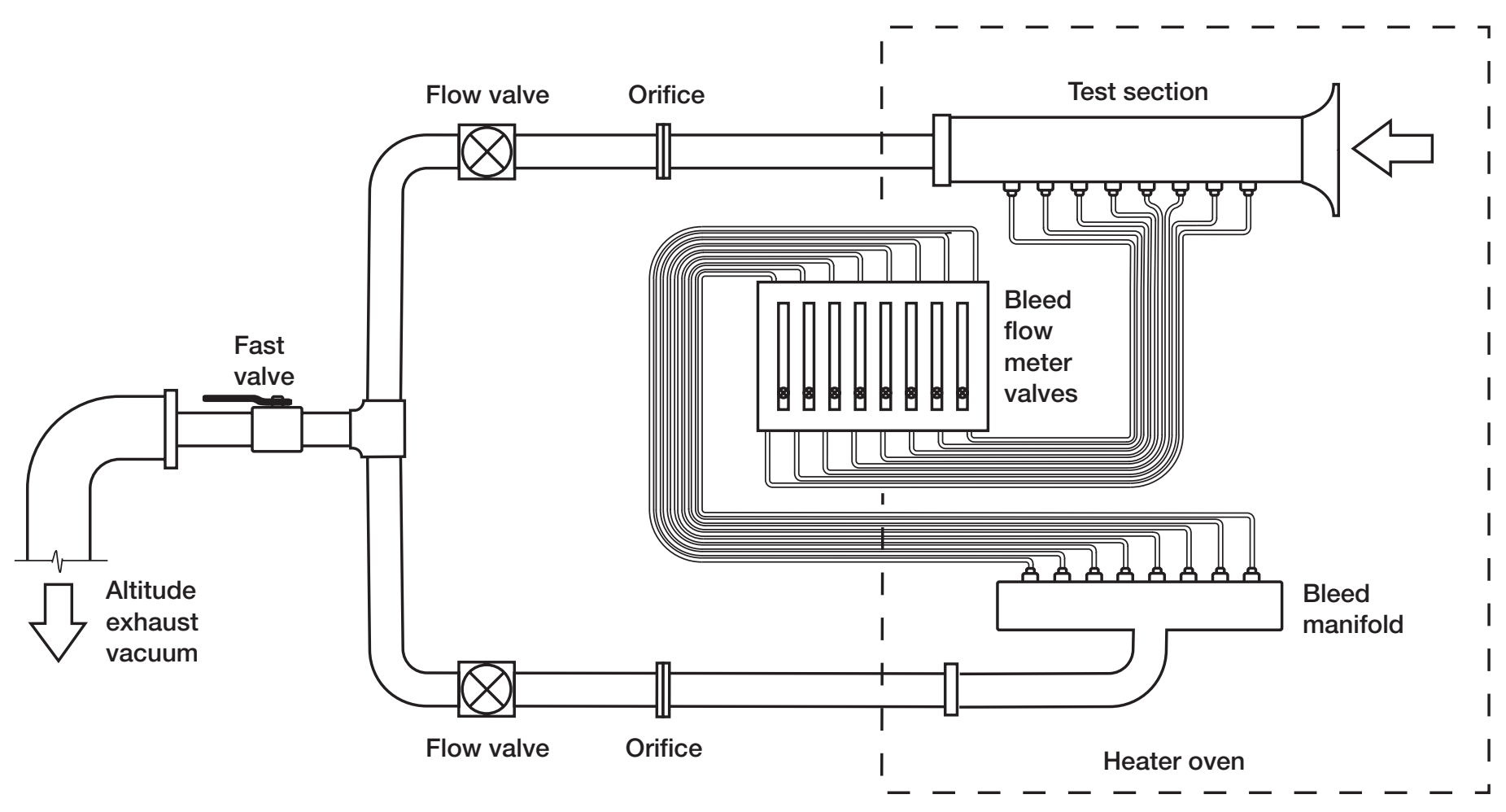

Figure 1.-Test Facility 

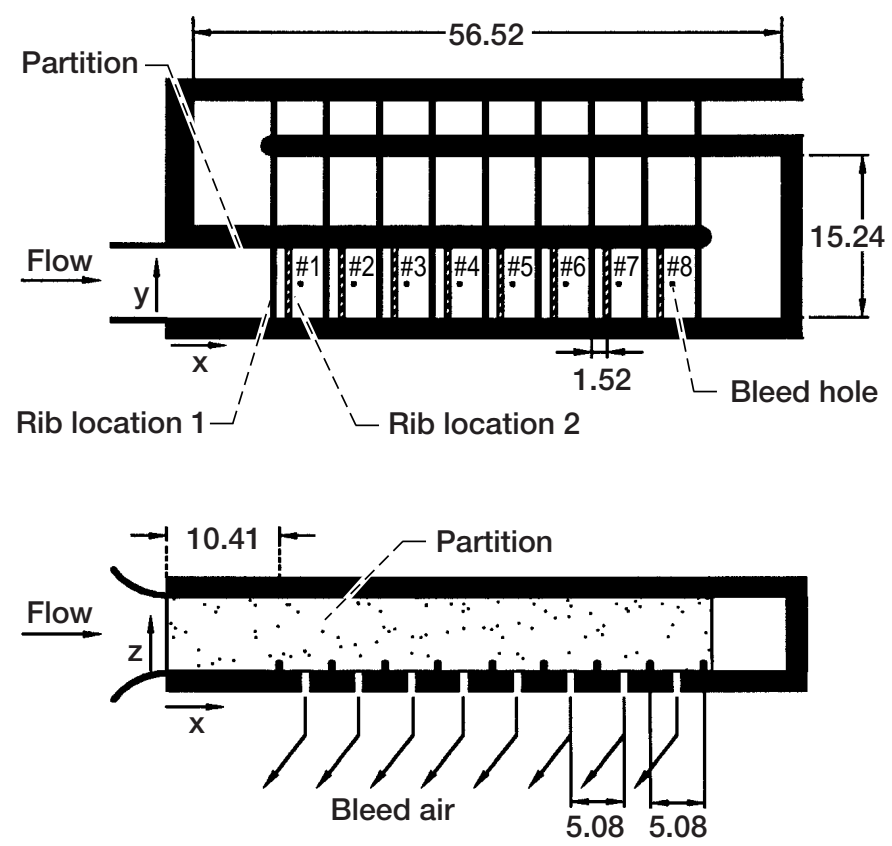

Figure 2.-Test section (units are in $\mathrm{cm}$ ).

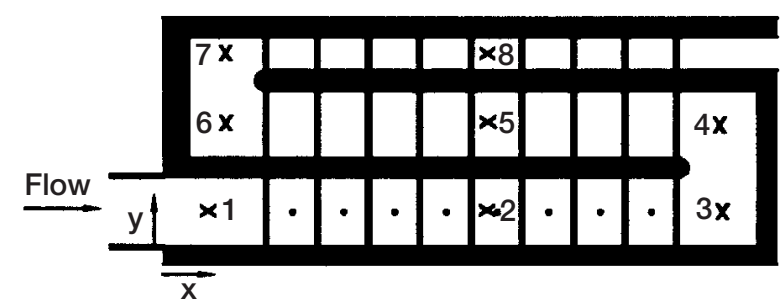

(a)

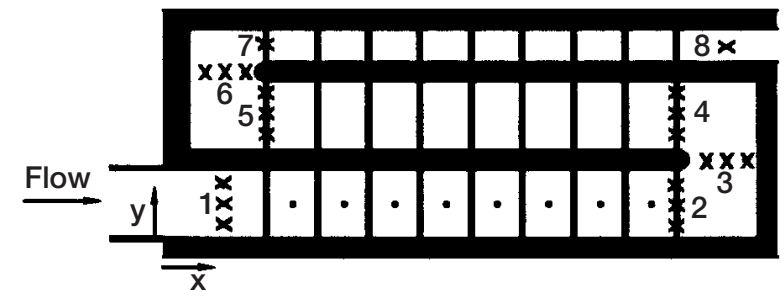

(b)

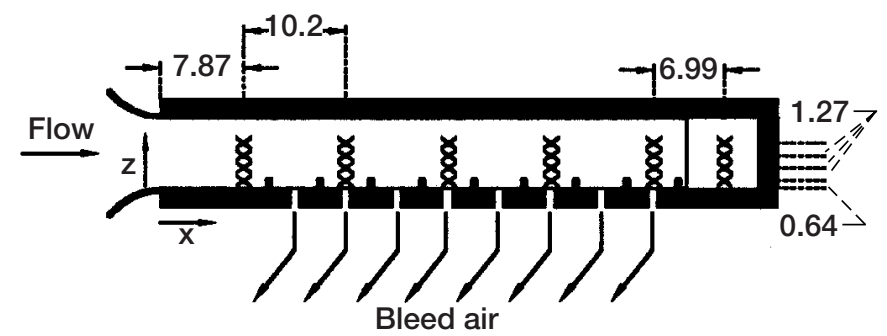

(c)

Figure 3.-(a) Static pressure measurement stations. (b) Air temperature measurement stations. (c) Air temperature measurement locations in first passage (units are in $\mathrm{cm}$ ). 

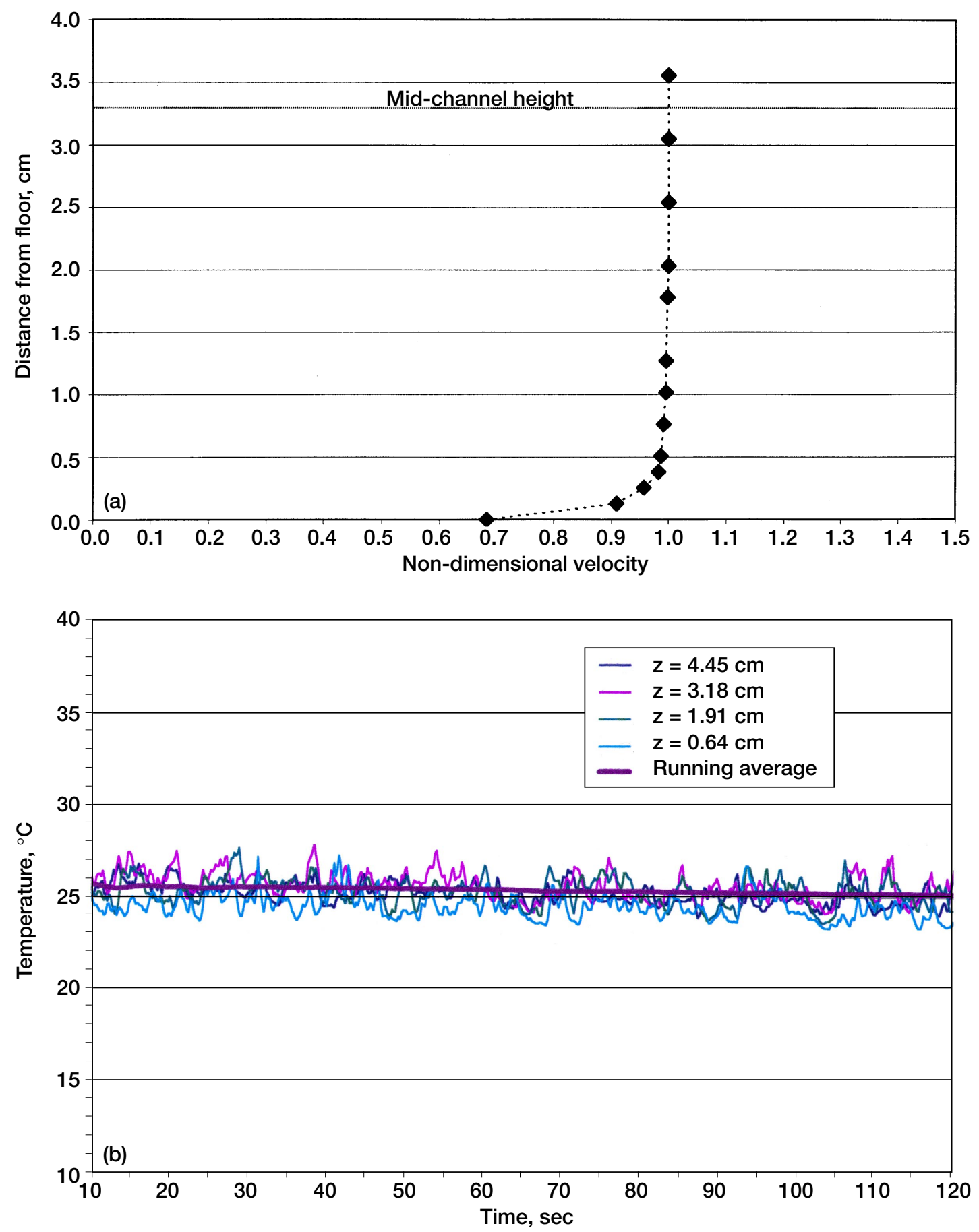

Figure 4.-(a) Inlet velocity profile. (b) Inlet airstream temperatures with uniform bleed at Re3. 

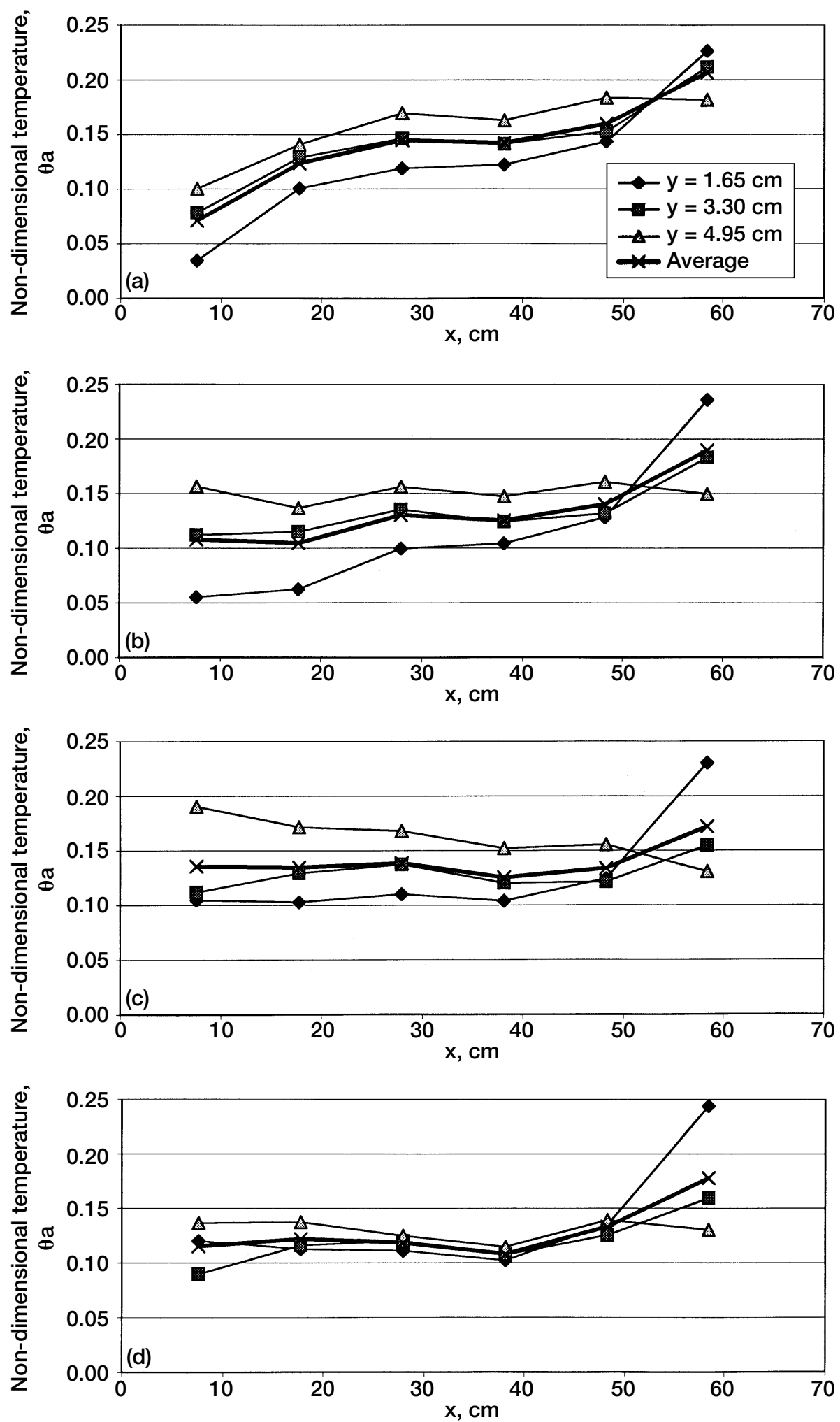

Figure 5.-Airstream temperature measurements at various heights in first channel with uniform bleed at Re3. (a) $z=.64 \mathrm{~cm}$. (b) $z=1.91 \mathrm{~cm}$. (c) $z=3.18 \mathrm{~cm}$. (d) $z=4.45 \mathrm{~cm}$. 


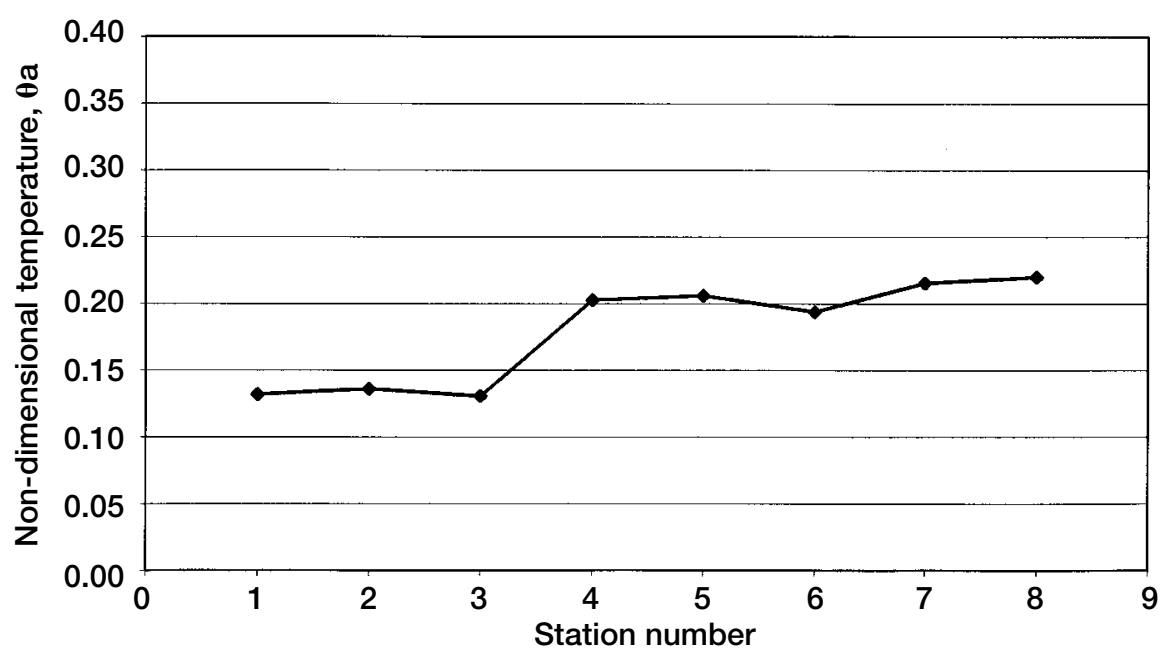

Figure 6.-Airstream temperature throughout model, averaged spanwise across channel, Re3, no bleed, mid-channel height.

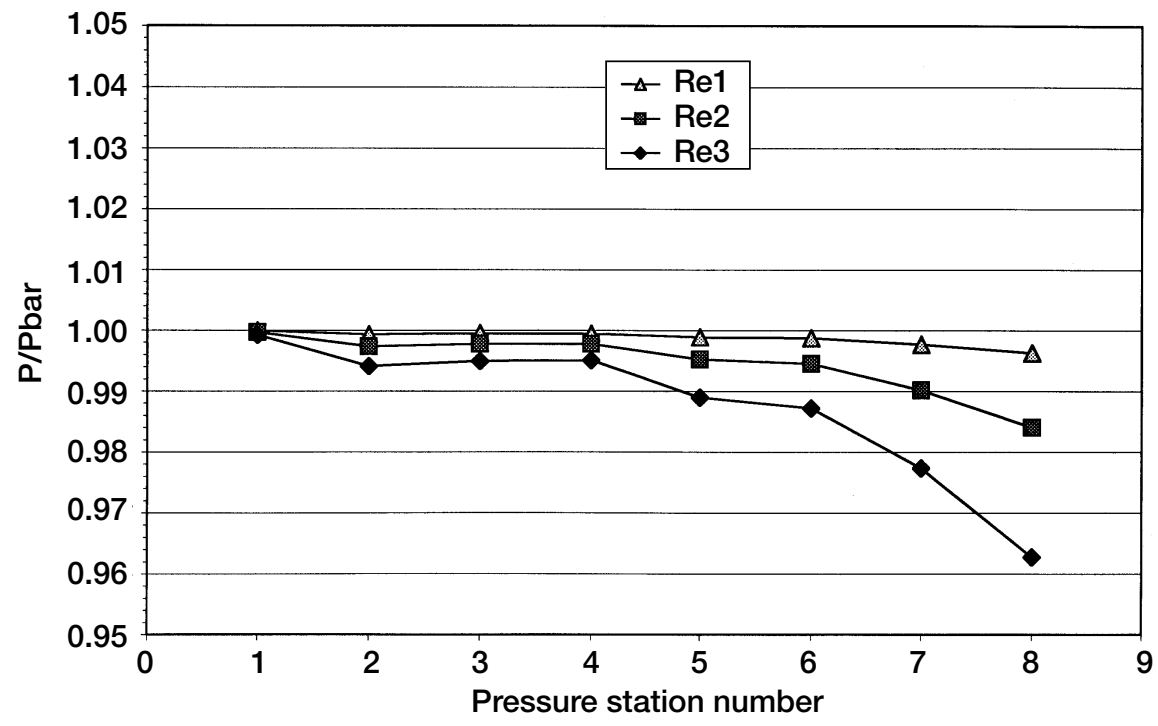

Figure 7.-Test section static pressures. Uniform bleed. 


\begin{tabular}{|c|}
\hline Nu/Nuo \\
\hline 7.0 \\
6.5 \\
\hline 6.0 \\
\hline 5.5 \\
5.0 \\
4.5 \\
4.0 \\
3.5 \\
3.0 \\
2.5 \\
2.0 \\
1.5 \\
1.0 \\
0.5 \\
\hline
\end{tabular}

(a)

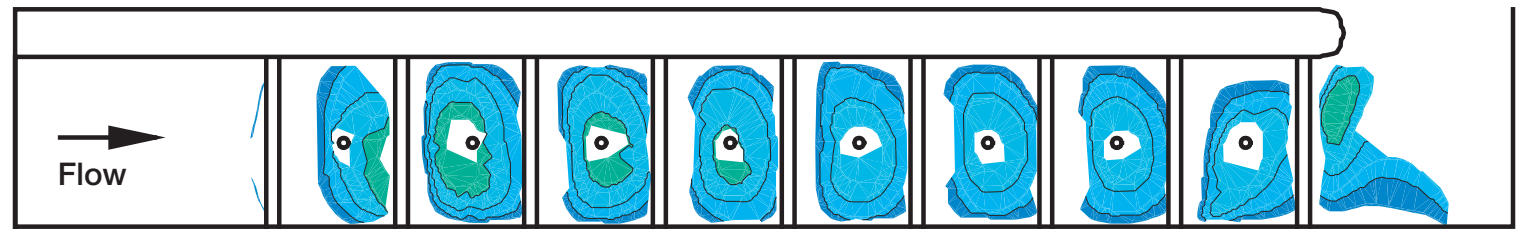

(b)

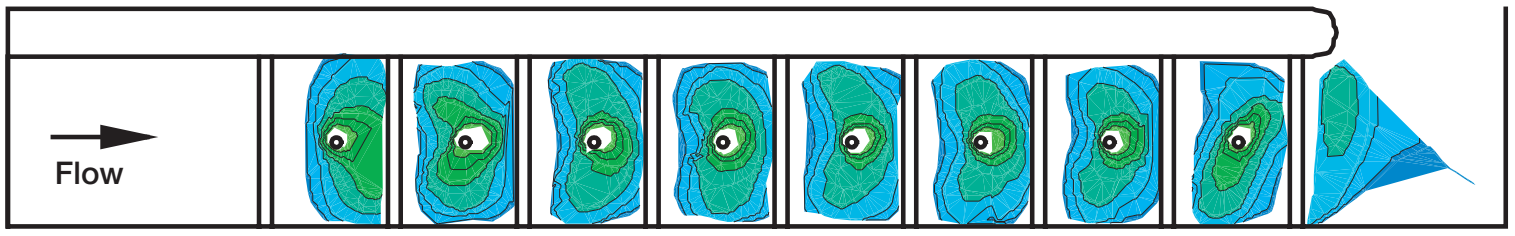

(c)

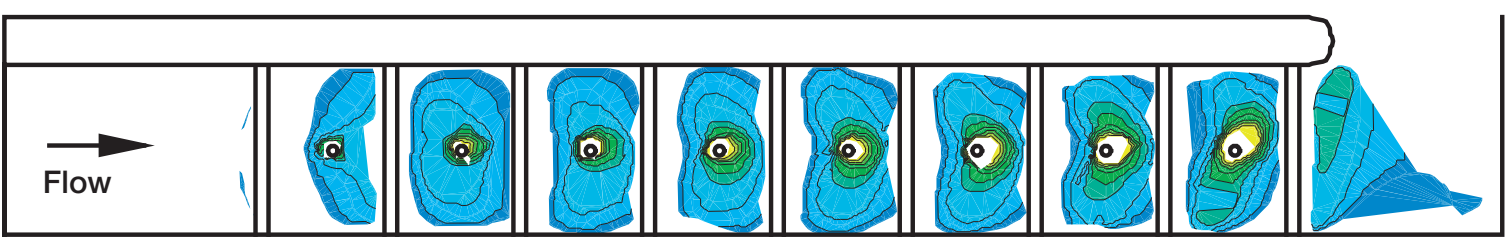

(d)

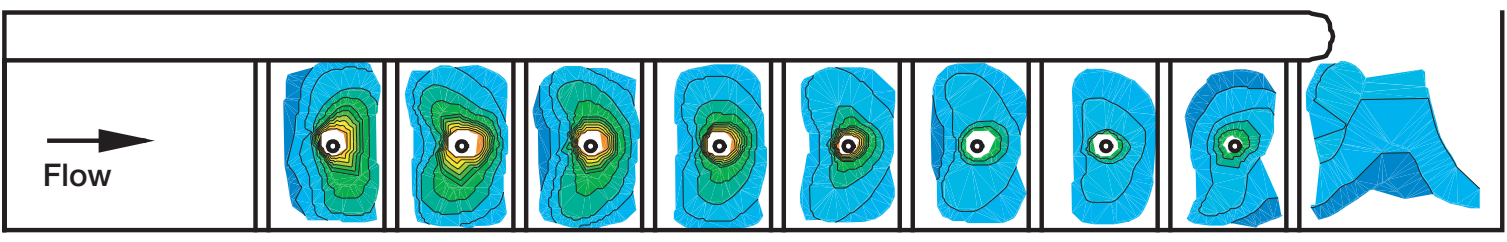

Figure 8.-Surface heat transfer, Nu/Nuo, for the case of ribs between holes. (a) Re1, no bleed. (b) Re1, uniform bleed. (c) Re1, increasing bleed. (d) Re1, decreasing bleed. 


\begin{tabular}{|c|}
\hline Nu/Nuo \\
\hline 7.0 \\
6.5 \\
6.0 \\
\hline 5.5 \\
\hline 5.0 \\
4.5 \\
4.0 \\
3.5 \\
3.0 \\
2.5 \\
2.0 \\
1.5 \\
1.0 \\
0.5 \\
\hline
\end{tabular}

(a)

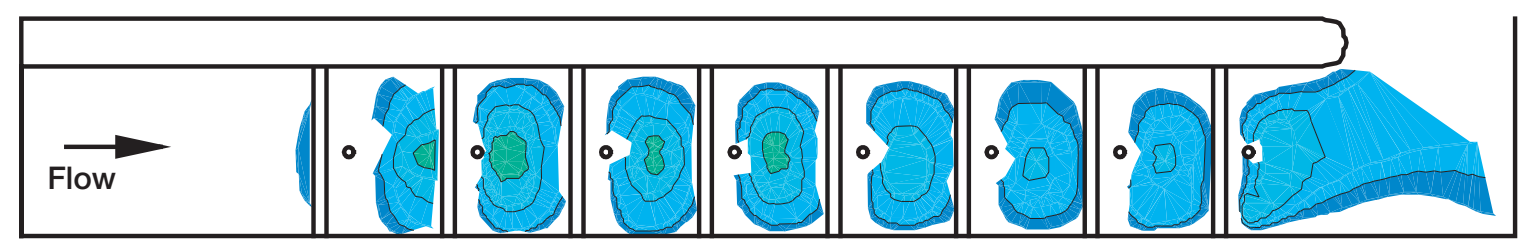

(b)

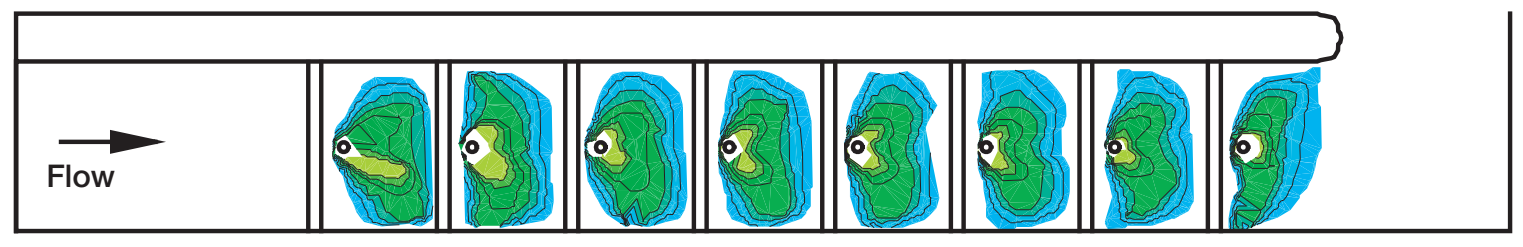

(c)

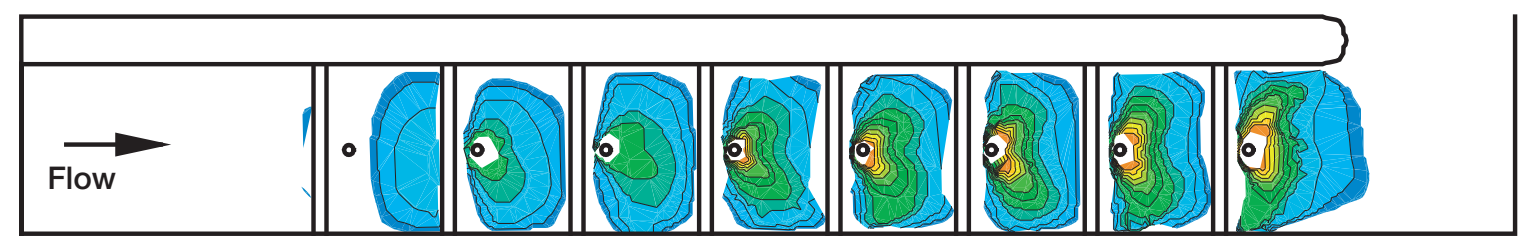

(d)

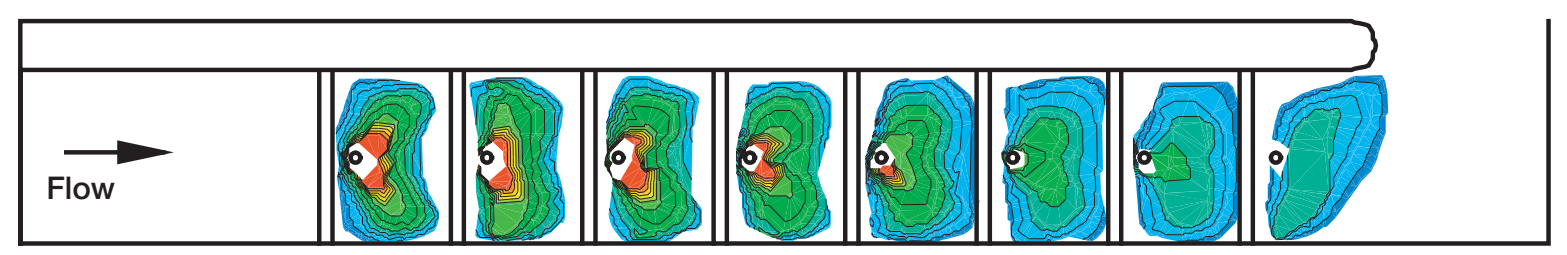

Figure 9.-Surface heat transfer, Nu/Nuo, for the case of ribs near holes. (a) Re1, no bleed. (b) Re1, uniform bleed. (c) Re1, increasing bleed. (d) Re1, decreasing bleed. 


\begin{tabular}{|c|}
\hline Nu/Nuo \\
7.0 \\
6.5 \\
6.0 \\
5.5 \\
5.0 \\
4.5 \\
4.0 \\
3.5 \\
3.0 \\
2.5 \\
2.0 \\
1.5 \\
1.0 \\
0.5 \\
\hline
\end{tabular}

(a)

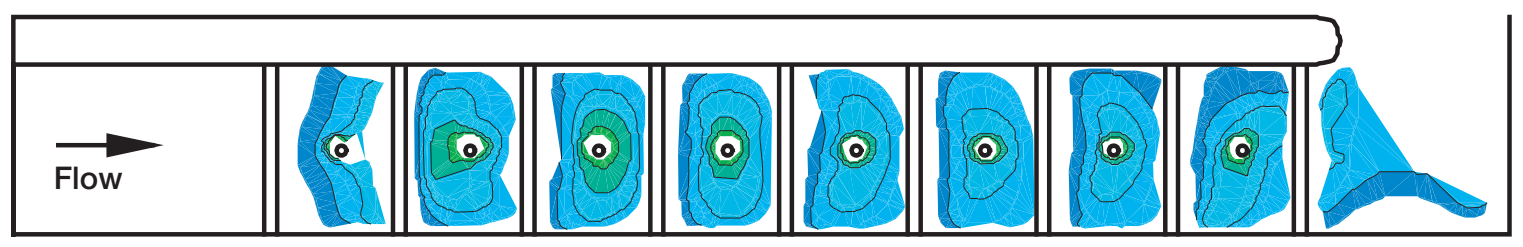

(b)

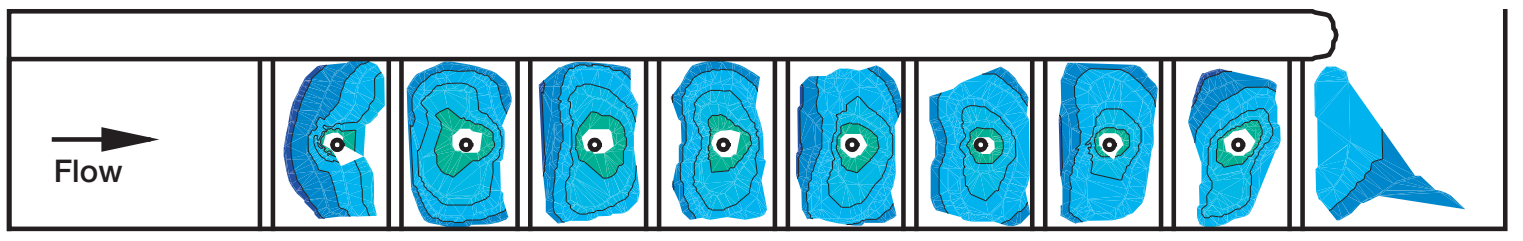

(c)

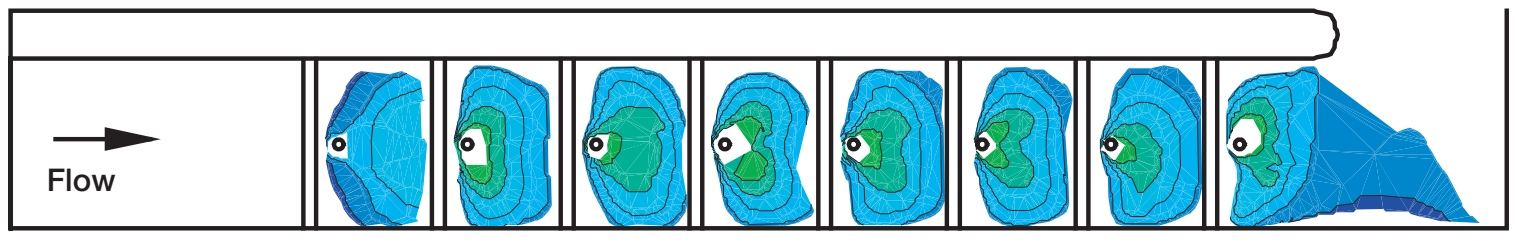

(d)

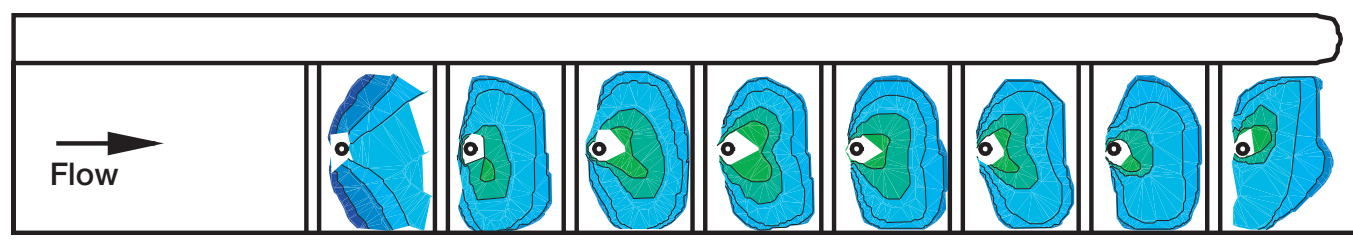

Figure 10.-Surface heat transfer, Nu/Nuo. (a) Re2, uniform bleed, ribs between holes. (b) Re3, uniform bleed, ribs between holes. (c) Re2, uniform bleed, ribs near holes. (d) Re3, uniform bleed, ribs near holes. 

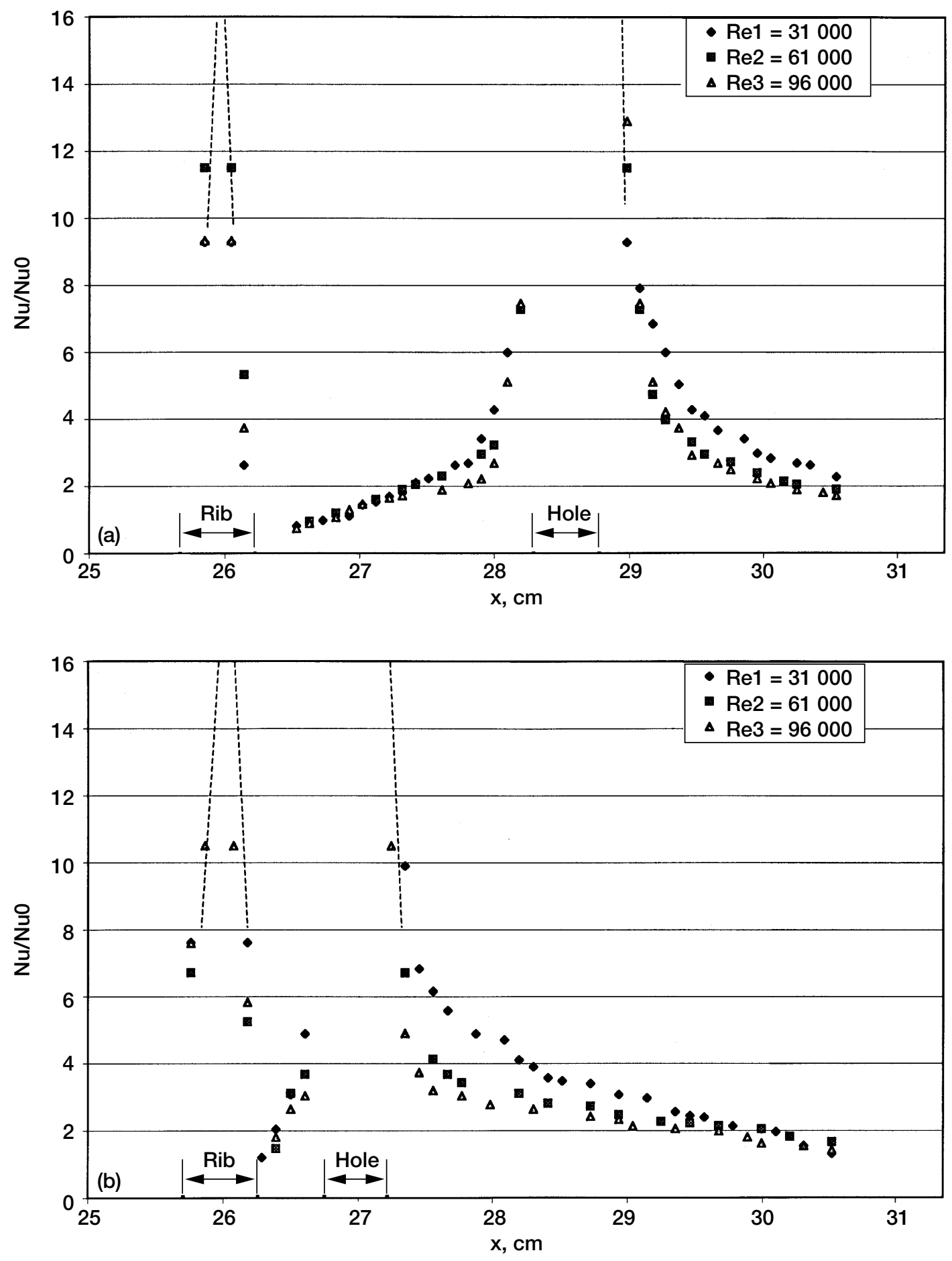

Figure 11.-Centerline heat transfer, uniform bleed. (a) Ribs between holes. (b) Ribs near holes. 
Public reporting burden for this collection of information is estimated to average 1 hour per response, including the time for reviewing instructions, searching existing data sources, gathering and maintaining the data needed, and completing and reviewing the collection of information. Send comments regarding this burden estimate or any other aspect of this collection of information, including suggestions for reducing this burden, to Washington Headquarters Services, Directorate for Information Operations and Reports, 1215 Jefferson Davis Highway, Suite 1204, Arlington, VA 22202-4302, and to the Office of Management and Budget, Paperwork Reduction Project (0704-0188), Washington, DC 20503.

\begin{tabular}{|l|l|l}
\hline 1. AGENCY USE ONLY (Leave blank) & $\begin{array}{c}\text { 2. REPORT DATE } \\
\text { January } 2000\end{array}$ & $\begin{array}{r}\text { 3. REPORT TYPE AND DATES COVERED } \\
\text { Technical Memorandum }\end{array}$ \\
\hline
\end{tabular}

\section{TITLE AND SUBTITLE}

Experimental Heat Transfer and Bulk Air Temperature Measurements for a Multipass Internal Cooling Model With Ribs and Bleed

6. AUTHOR(S)

Douglas Thurman and Philip Poinsatte

\section{FUNDING NUMBERS}

WU-523-26-13-00

1L162211A47A
8. PERFORMING ORGANIZATION REPORT NUMBER

NASA Glenn Research Center

Cleveland, Ohio 44135-3191

and

U.S. Army Research Laboratory

Cleveland, Ohio 44135-3191

\section{SPONSORING/MONITORING AGENCY NAME(S) AND ADDRESS(ES)}

National Aeronautics and Space Administration

Washington, DC 20546-0001

and

U.S. Army Research Laboratory

Adelphi, Maryland 20783-1145
E-12042

10. SPONSORING/MONITORING AGENCY REPORT NUMBER

NASA TM-2000-209772

ARL-MR-471

\section{SUPPLEMENTARY NOTES}

Prepared for the 45th ASME International Gas Turbine Institute sponsored by the American Society of Mechanical Engineers, Munich, Germany, May 8-11, 2000. Douglas Thurman, U.S. Army Research Laboratory, NASA Glenn Research Center, and Philip Poinsatte, NASA Glenn Research Center. Responsible person Philip Poinsatte, organization code 5820, (216) 433-5898.

12a. DISTRIBUTION/AVAILABILITY STATEMENT

12b. DISTRIBUTION CODE

Unclassified - Unlimited

Subject Category: 34

Distribution: Nonstandard

This publication is available from the NASA Center for AeroSpace Information, (301) 621-0390.

\section{ABSTRACT (Maximum 200 words)}

An experimental study was made to obtain heat transfer and air temperature data for a simple 3-leg serpentine test section that simulates a turbine blade internal cooling passage with trip strips and bleed holes. The objectives were to investigate the interaction of ribs and various bleed conditions on internal cooling and to gain a better understanding of bulk air temperature in an internal passage. Steady state heat transfer measurements were obtained using a transient technique with thermochromic liquid crystals. Trip strips were attached to one wall of the test section and were located either between or near the bleed holes. The bleed holes, used for film cooling, were metered to simulate the effect of external pressure on the turbine blade. Heat transfer enhancement was found to be greater for ribs near bleed holes compared to ribs between holes, and both configurations were affected slightly by bleed rates upstream. Air temperature measurements were taken at discreet locations along one leg of the model. Average bulk air temperatures were found to remain fairly constant along one leg of the model.

\section{SUBJECT TERMS}

Heat transfer; turbomachinery; gas turbines; bleeding; cooling; ribs temperature measurement

\begin{tabular}{|c|c|c|}
\hline $\begin{array}{c}\text { 17. SECURITY CLASSIFICATION } \\
\text { OF REPORT } \\
\text { Unclassified }\end{array}$ & $\begin{array}{c}\text { 18. SECURITY CLASSIFICATION } \\
\text { OF THIS PAGE } \\
\text { Unclassified }\end{array}$ & $\begin{array}{c}\text { 19. SECURITY CLASSIFICATION } \\
\text { OF ABSTRACT } \\
\text { Unclassified }\end{array}$ \\
\hline
\end{tabular}

